\title{
OXIDATIVE STRESS AND THIOLS DEPLETION IMPAIR TIBIA FRACTURE HEALING IN YOUNG MEN WITH TYPE 2 DIABETES
}

\author{
H. I. FALFUSHYNSKA ${ }^{1 凶, ~ O . ~ I . ~ H O R Y N ~}{ }^{1}$, D. V. POZNANSKY $Y^{1}$, D. V. OSADCHUK ${ }^{2}$, \\ T. O. SAVCHYN ${ }^{3}$, T. I. KRYTSKYI ${ }^{2}$, L. S. MERVA', S. Z. HRABRA ${ }^{1}$ \\ ${ }^{1}$ Ternopil Volodymyr Hnatiuk National Pedagogical University, Ukraine; \\ ${ }^{2}$ I. Horbachevsky Ternopil National Medical University, Ukraine; \\ ${ }^{3}$ Ternopil Ivan Puluj National Technical University, Ukraine; \\ 凶e-mail: falfushynska@tnpu.edu.ua
}

Received: 05 May 2019; Accepted: 18 October 2019

\begin{abstract}
Diabetes mellitus is a metabolic disorder that enhances fracture risk and hinders bone formation. The aim of the present study was to evaluate the parameters of oxidative stress, metallothioneins (MTs), metabolic changes and cytotoxicity signs in blood of young men with (DTF group) and without (TF group) type 2 diabetes (T2D) mellitus who had a tibia fracture due to trauma in relation to specific markers of bone formation. The level of reactive oxygen species was determined using a ROS-sensitive fluorescent dye dihydrorhodamine, DNA fragmentation was detected with Hoescht 33342 fluorescent dye and caspase-3 was assessed in terms of acetyl-Asp-Glu-Val-Asp p-nitroanilide. All other studied indices were determined by standard spectrometric methods. Our results revealed the significant effect of T2D on the bone healing. Indeed, the indices variation in the DTF group were significantly deeper as compared to group TF. The bone fracture in both TF and DTF groups had led to a significant decrease in antioxidants activity and/or level and a consistent increase in signs of oxidative damage. The concentration of MTs was also altered by trauma, but ina group-specific manner: an increase was noted in TF patients after trauma while in diabetes group a decrease in MTs was observed. Likewise, glutathione was strongly suppressed (by -64\%) in DTF group. Tibia fracture provoked cytotoxicity which was manifested by increasing lactate dehydrogenase $(L D H)$, cholinesterase and caspase-3 activity, the key effector of apoptosis in osteoclasts. The activity of alkaline phosphatase and total calcium increased only in TF group which demonstrated adequate remodelling process. The most prominent indices for groups splitting include ROS concentration, caspase 3, glutathione transferase and LDH activities mostly conjoint to DTF group. In sum, T2D impairs bone healing under condition of severe oxidative stress and cellular thiols depletion which result in an increase in apoptosis and DNA fragmentation. Our findings establish a biochemical link between increased oxidative stress and reduced bone markers and provide a rational for further studies investigating the role of pro- and antioxidants in bone healing.
\end{abstract}

Ke y w o rd s: tibia fracture, oxidative stress, markers of bone formation.

$\mathrm{F}$ racture and trauma are accountable for an increasing fraction of the global burden of disorders, and show a major humane, socioeconomic, medical, and research challenge [1]. The expected outcome of a fracture is the bone healing, but up-to-date it is estimated that $5-10 \%$ of all patients with long bone fractures should develop impaired fracture healing processes due to numerous internal and external factors among them concomi- tant pathology, nutrition, hormonal status and drugs $[2,3]$. The tibia fractures in regards to the unique characteristics of this bone, are the most often affected by the phenomena of disturbances of the bone healing process, in which non-union occurs in up to $10-20 \%$ of patients with tibial shaft fractures. In clinical practice, the fracture healing process is usually evaluated by physical and radiographic examinations. However, biomedically validated methods

(c) 2019 Falfushynska H. I. et al. This is an open-access article distributed under the terms of the Creative Commons Attribution License, which permits unrestricted use, distribution, and reproduction in any medium, provided the original author and source are credited. 
to reflect healing progression and early warning of fracture healing complications have not been known yet. In this behalf, a valid spectrum of biochemical markers should be discovered to evaluate the efficiency of the bone healing process [4].

Oxidative stress plays an essential role in the development and progress of different pathologies and complications [5, 6]. A regulated increase of ROS level would be crucial in the transmission of intracellular signaling that controls a lot of fundamental cellular processes such as proliferation, differentiation, growth, apoptosis, repair processes and inflammation [7]. Indeed, oxidative stress violates the bone remodeling process causing a misbalance between osteoclasts and osteoblasts [8]. This can lead to metabolic bone disorders and impairment of the skeletal system in regards to low bone mineral density and decrease in bone mass, which makes the bone weak and more prone to fracture.

Diabetes mellitus is a metabolic disorder that enhances fracture risk and hinders fracture healing and bone formation [9]. Type 2 diabetes mellitus is associated with an increased risk of osteoporosisassociated fractures [10] due to increased load on bone and the accumulation of advanced glycation end products in collagen, ROS generation, enhancing expression of cytokines such as tumor necrosis factor and inflammation [11, 12]. These factors affect both osteoblasts and osteoclasts bring to misbalance between cells, namely increased ratio osteoclasts/ osteoblasts and impair bone formation. Meanwhile, the relationship between hyperglycemia and fracture risk does not seem to be linear. Numerous studies have reported contradiction results, which sometimes varied from an increase in risk to a decrease in risk, when compared those with impaired glucose tolerance to those with normoglycemia [13].

Metallothioneins (MTs) are stress-responsive, cysteine-rich, metal-binding, intra- and extracellular (including serum) proteins that are induced by and adapts to numerous stressful conditions [14, 15]. Besides the transition metal detoxification and radical scavenging, MTs were also found to play an important role in immune response, cell proliferation and differentiation, and angiogenesis [14, 15]. MTs would build a thiol pool up in cell cytosol which is able to diminish the damaging effect of GSH depletion. MTs as the redox-sensitive adapter proteins could release $\mathrm{Zn}^{2+}$ from metal-thiolate clusters in response to prooxidant milieu and oxidative damage [14], a status often found in the tissues of diabetic patients, obvi- ously reflecting persistent hyperglycemia and could prevent diabetes or its complications by inactivation of MAPK pathways [16]. However, the information regarding MTs and, in particular extracellular, and its potentials for the effective regulation of ROS under diabetic conditions and particularly in combination with additional pathology is not available in detail.

Therefore, the aim of the present work was to study the parameters of oxidative stress, metallothioneins (MTs), metabolic changes and cytotoxicity signs in blood of young men with (DTF group) and without (TF group) type 2 diabetes (T2D) mellitus who had a tibia fracture due to trauma in relation to specific markers of bone formation. According to our previous works [17-20], the set of stress-responsive system's indices includes the parameters of the oxidative stress, metabolic status, and metallothioneins.

\section{Materials and Methods}

Experimental design. We have screened the blood samples of 12 healthy volunteer fellows (Cgroup), 12 fellows with tibia fractures (TF-group) and 12 fellows with tibia fractures (within $24 \mathrm{~h}$ of injury) and type 2 diabetes (T2D) mellitus (DTFgroup) (within $24 \mathrm{~h}$ of injury) aged 20-25 years who were admitted to the trauma ward of the Ternopil city hospital. Type 2 diabetes was defined for all patients, a fasting blood glucose level of 7-9 mmol/l, $2 \mathrm{~h}$ post-challenge glucose $11.3-12.6 \mathrm{mmol} / \mathrm{l}$, and a HbA1c 6.5-7.1\%. Participants have been being at diabetes from the age of 15 . No concomitant pathology for T2D patients was identified. All patients gave written informed consent, and the study procedures were in accordance with the Declaration of Helsinki. Ethics approval was given by the local ethics committee on human research. All applicable international, national, and/or institutional guidelines for the care and use of animals were followed. All experimental studies were conducted in accordance with the rules of the National Congress on Bioethics (Kyiv, 2000) and the experimental protocol was approved by the Committee of Ethics in Ternopil Volodymyr Hnatiuk National Pedagogical University (No 2, 2018).

Venous blood samples were collected from target volunteers to chilled vacutainer tubes with no additives for serum isolation and to polypropylene tubes containing $\mathrm{K}_{2}$ EDTA $(1.5 \mathrm{mg} / 1 \mathrm{ml})$ as anticoagulant for blood plasma isolation. Samples were 
centrifuged at $1000 \times \mathrm{g}$ for $15 \mathrm{~min}$ at $4{ }^{\circ} \mathrm{C}$. After centrifugation of blood samples, the obtained plasma/ serum kept frozen until measurements.

All the procedures on cells were carried out at $4{ }^{\circ} \mathrm{C}$. All chemicals were purchased from Sigma Aldrich (St. Louis, USA) or Merck, and were of the analytical grade or higher.

Specific markers of bone formation. The calcium and alkaline phosphatase (EC 3.1.3.1) were measured with diagnostic "LaChema" spectrometric kits according to the manufacturer's instructions.

Oxidative stress parameters. Catalase activity (EC 1.11.1.6) was measured in whole blood samples by Aebi method [21], which is based on the decomposition of hydrogen peroxide with the catalase derived from the sample. The test mixture contained $50 \mathrm{mg}$ of protein in $50 \mathrm{mM} \mathrm{K}$-phosphate buffer, $\mathrm{pH} 7.4$ in the presence of $15 \mathrm{mM} \mathrm{H}_{2} \mathrm{O}_{2}$ in total volume of $3.0 \mathrm{ml}$. The reaction was initiated by adding the appropriate volume of blood sample, and then the absorbance at $240 \mathrm{~nm}$ within a 60 -second interval was determined. Enzymatic activity was calculated by the millimolar coefficient of the hydrogen peroxide's absorbance $\left(\varepsilon=-0.04 \mathrm{mM}^{-1} \cdot \mathrm{cm}^{-1}\right)$ and expressed in $\mu \mathrm{mol} /(\mathrm{mg}$ of protein $\times \mathrm{min})$.

The content of oxyradicals in the supernatant of the whole blood sample $(1: 10 \mathrm{v} / \mathrm{v})$ in $0.32 \mathrm{M}$ sucrose, $20 \mathrm{mM}$ HEPES (pH 7.4), $1 \mathrm{mM} \mathrm{MgCl}_{2}$, $0.5 \mathrm{mM}$ phenylmethylsulfonyl fluoride after it centrifuging at $16000 \times \mathrm{g}$ for $45 \mathrm{~min}$ at $4^{\circ} \mathrm{C}$ were determined using a ROS-sensitive fluorescent dye dihydrorhodamine which is converted by ROS to the fluorescent dye rhodamine-123 [22]. The probe fluorescence signal was detected by using $f$-max fluorescence plate-reader [excitation (ex.) $=485 \mathrm{~nm}$, emission $(\mathrm{em})=.538 \mathrm{~nm}$ ] at time 0 and after $20 \mathrm{~min}$, and the rates of ROS formation were calculated from these two values. The oxyradicals were expressed in relative fluorescence units (RFU) per $1 \mathrm{mg}$ of protein.

Protein carbonyl (PC) concentration, as an index of protein oxidation, was measured in the TCAtreated blood samples by the reaction with 2,4-dinitrophenylhydrazine (DNPH) [23]. Differences in the absorbance between the DNPH- and the HCl-treated samples were determined spectrophotometrically at $370 \mathrm{~nm}$, and the amount of carbonyls was determined by using the molar extinction coefficient of $2.2 \cdot 10^{4} \mathrm{M}^{-1} \mathrm{~cm}^{-1}$. Data were expressed as nmol PC $\cdot \mathrm{mg}^{-1}$ of soluble extracted protein.

Lipid peroxidation (LPO) was determined in the protein-free supernatant of blood samples by the production of thiobarbituric acid-reactive sub- stances (TBARS) [24]. The formation of TBARS was calculated by the intensity of the absorption of a pink-colored complex at $532 \mathrm{~nm}$ by the molar extinction coefficient of the complex equal to $\varepsilon=1.56 \cdot 10^{5} \mathrm{M}^{-1} \cdot \mathrm{cm}^{-1}$.

Cellular thiol pool. The content of total glutathione was quantified in the blood plasma by the glutathione reductase recycling assay [25]. To estimate the oxidized glutathione (GSSG) level, the protein-free sample was treated with 2-vinylpyridine 60 min prior to the assay at $2 \%$ final concentration [26]. The rate of 5-thionitrobenzoic acid formation was monitored spectrophotometrically at $412 \mathrm{~nm}$. The concentration of reduced glutathione (GSH) was calculated as the difference of concentrations between total glutathione and its oxidized forms.

Metallothioneins (MTs) were determined in the blood plasma from thiols measure with 5,5'-dithiobis-2-nitrobenzoic acid according to the method of Viarengo [27] after the ethanol/chloroform extraction. The concentrations of MTs were calculated using the relationship: $1 \mathrm{~mol} \mathrm{MTs}=20 \mathrm{~mol} \mathrm{GSH}$ and were expressed as $\mu \mathrm{g}$ of MTs per ml blood.

Glutathione-S-transferase (GST, EC 2.5.1.18) activity was measured in the blood plasma according to [28] using 1-chloro-2,4-dinitrobenzene as a substrate. Enzyme activity was determined at $25{ }^{\circ} \mathrm{C}$ by monitoring changes in absorbance at $340 \mathrm{~nm}$ for 2 min at constant temperature. The GST activity was expressed as nmol $\mathrm{min}^{-1} \cdot \mathrm{mg}^{-1}$ protein.

Markers of cytotoxicity. The activity of lactate dehydrogenase (LDH, EC 1.1.1.27) was determined in blood serum samples using the UV assay with pyruvate and NADH [29] by determining of the amount of NADH oxidation at $340 \mathrm{~nm}$. A molar extinction coefficient of $6.22 \cdot 10^{6} \mathrm{M}^{-1} \cdot \mathrm{cm}^{-1}$ was used.

Cholinesterase (ChE, EC 3.1.1.7) activity was determined in the blood serum as the acetylthiocholine-cleaving $\mathrm{ChE}$ activity at $25^{\circ} \mathrm{C}$ according to the colorimetric method of Ellman et al. [30]. Enzyme activity was calculated using a molar extinction coefficient of $13.6 \cdot 10^{3} \mathrm{M}^{-1} \mathrm{~cm}^{-1}$ and standardized to the soluble protein content [29].

For the characteristic of apoptosis, the activity of an executor caspase-3 was detected in samples of volunteers' blood serum. The protocol is based on the hydrolysis of peptide acetyl-Asp-GluVal-Asp p-nitroanilide (Ac-DEVD-pNA) by caspase-3 that produces a colored product p-nitroaniline (pNA). p-Nitroaniline is evaluated at $405 \mathrm{~nm}$ $\left(\varepsilon_{\mathrm{mM}}=10.5 \mathrm{mM}^{-1} \cdot \mathrm{cm}^{-1}\right)[18,31]$. 
The DNA damage was evaluated by the levels of protein-free DNA strand breaks in the 1:10 (v/v) blood serum in $50 \mathrm{mM}$ Tris-EDTA buffer, $\mathrm{pH} 8.0$ which contains $0.5 \%$ sodium dodecyl sulphate (SDS) by the alkaline DNA precipitation assay [32] using Hoescht 33342 dye. To reduce the possible interference with traces of (SDS), the assay was carried out in the presence of $0.4 \mathrm{M} \mathrm{NaCl}, 4 \mathrm{mM}$ sodium cholate, and $0.1 \mathrm{M}$ Tris (pH 9). Probe fluorescence signal was detected using $f$-max fluorescence plate-reader (excitation $=360 \mathrm{~nm}$, emission $=450 \mathrm{~nm}$ ). The content of fragmented DNA was expressed as a mass fraction of DNA strand break in a sample to the total DNA.

Statistical analysis. Data were tested for normality and homogeneity of variance by using Kolmogorov-Smirnoff and Levene's tests, respectively. Whenever possible, data were normalized by BoxCox common transforming method. For the data that were not normally distributed even after the transformation, non-parametric tests (Kruskall-Wallis ANOVA and Mann-Whitney U-test) were performed. Pearson's correlation test was used to assess correlations between the studied traits. Normalized, Box-Cox transformed data were subjected to the principal component analysis (PCA) to differentiate the individual specimens by the set of their indices. All statistical calculations were performed with Statistica v. 12.0 and Excel for Windows-2013. Differences were considered significant if the probability of Type I error was less than 0.05. For all biological traits and all studied groups, sample size was 12 . The data are presented as means \pm standard deviation (SD).

The integrated biomarker response (IBR) indexes were calculated using CALculate IBR Interface (Calibri, https://liec-univ-lorraine.shinyapps.io/ calibri/) proposed by Laboratory for Continental Environments (LIEC) of Lorraine University. We calculated the IBR in terms of the most sensitive indices had selected using Discriminant analysis. The integral index of oxidative stress (IOS) was calculated as the ratio of antioxidants (catalase, glutathione reduced, metallothioneins, glutathione-S-transferase) to prooxidants (TBARS, protein carbonyls, ROS, glutathione oxidized) after data standardization.

\section{Results and Discussion}

Effects of tibia fracture on oxidative stress parameters. The response of oxidative stress parameters after trauma have disclosed significant groupspecific relation $\left(\mathrm{F}_{3,20}>9.1, P<0.001\right)$. The indices variation in group DTF were significantly deeper as compared to group TF. The bone fracture in both TF and DTF groups had led to a significant decrease in antioxidants activity and/or level and a consistent increase in signs of oxidative damage. There was a significant decrease in the catalase activity in both groups TF and DTF patients as compared to the correspondent controls (Fig. 1, A), particularly in DTF (by $82 \%$ ). Meanwhile, a notable increase in the ROS formation, lipid peroxidation and protein carbonylation was found for all studied groups of patients (Fig. 1, B-D).

Status of cellular thiol pool and bone markers. As a group, patients with fracture (combining those with T2D) had lower GSH reduced concentrations, but not GSSG compared to controls (Fig. 2, $A, B)$. GST activity was lower in examined patients without coexistent disease when compared to the correspondent control, but in persons with diabetes significantly increased (Fig. 2, C). The concentration of MTs was also altered, an increase was noted in patients after trauma without T2D while diabetes favored a decrease in MTs (Fig. 2, D).

Bone markers, calcium level and alkaline phosphatase activity were markedly increased only in TF-group, but decreased when DTF-group was observed (Fig. 3).

Signs of cytotoxicity. Bone fracture had a significant impact on caspase-3 activity (Fig. 4, A). The most prominent two-fold increase was revealed for patients of DTF-group. Nevertheless, bone fracture triggered apoptosis pathway, there were no differences in DNA strand breaks between controls and patients with bone fracture both with or without complications (Fig. 4). LDH activity and ChE activity were increased in patients, but in different range depends on complications.

Data integration. The PCA analysis with NIPALS algorithm of the studied biological traits revealed group-specific allocation of the biomarkers (Fig. 5, A). The principal component analysis showed that $85 \%$ of variation in the studied traits was explained by the first two principal components (PC 1 and 2) (Fig. 5, A). Control and groups with disorders were separated one from another in two plains: on the one hand control and groups with disorders were intelligibly divided along second principal component, on the other hand, groups with disorders, TF and DTF were split up by first principal component. Control group reflected by GSH, than the DTF group was conjoint to ROS concentration, 

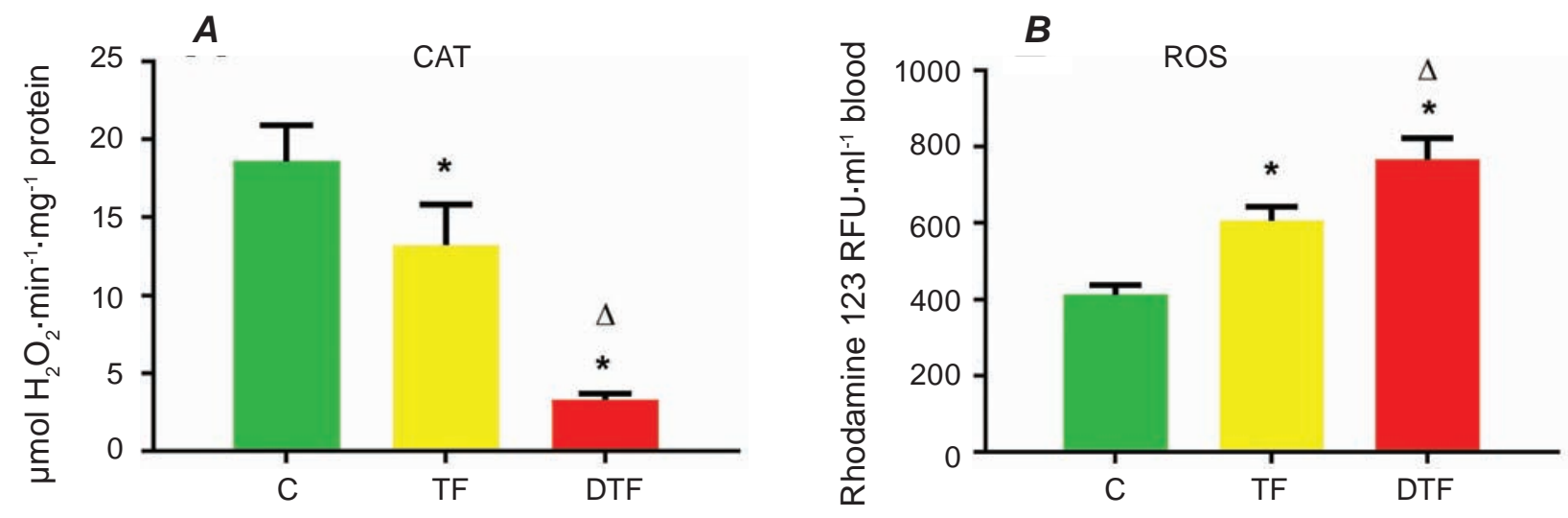

C
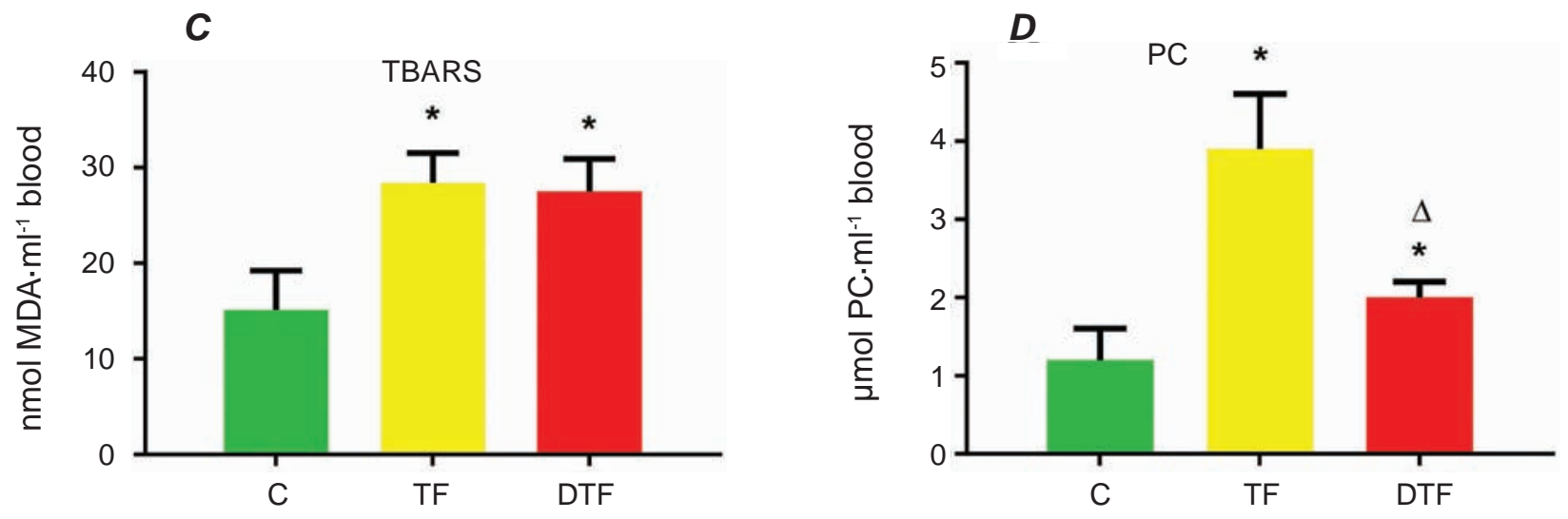

Fig. 1. Oxidative stress parameters in the blood of young men without (TF) and with (DTF) diabetes as concomitant pathology soon after a tibia fracture. Data for A: Catalase, B: reactive oxygen species, C: TBARS, $D$ : protein carbonyls, are present as means $\pm S D(n=12)$. Here and there, * means that the values in volunteers of control group $(C)$ and patients with (DTF group) and/or without (TF group) type 2 diabetes mellitus who had a tibia fracture are differed significantly $(P<0.05) ; \Delta$ discloses significant changes between patients of DTF group and TF group

caspase 3, GST and LDH activities. The largest data set was associated with the TF group and included bone markers (Ca concentration, ALP activity), protein carbonyls, MTs and ChE activity. Moreover, TF group associated with "positive" parameters reflected adequate bone healing, but DTF with "negative" namely ROS, TBARS and caspase-3 activity when integral biomarker response (IBR) index was calculated (Fig. 5, B). Also, we calculated integral index of oxidative stress (IOS) using studied oxidative stress parameters after standardization and it showed deeper oxidative injury in DTF patients than in TF one $(\mathrm{IOS}=-34 \%$ for $\mathrm{TF}$ group and $-55 \%$ for DTF group).

TF patients demonstrated an increase in the alkaline phosphatase activity in the site of callus formation soon after fracture [33], whereas a decrease in alkaline phosphatase activity took place in the DTF group. Osteocalcin levels were followed by a considerable reduction in bone formation [34]. In the present study, the activity of alkaline phosphatase and total calcium increased only in TF patients which emphasized the adequate remodelling process in this group. Meanwhile, patients of DTFgroup with diabetes demonstrated deep inhibition of alkaline phosphatase conjoined with decreasing in calcium level ( $r=0.85, P<0.001)$. This inhibition might be due to the overload by the products of oxidative damage, which could inhibit osteogenic cells that provide osteocalcin, alkaline phosphatase, and other proteins. Obviously, the amount of ROS and oxidative lesions in diabetes patients when they face bone fractures should be corrected by antioxidants therapy for better recovering. Supporting our supposition, it has been found that antioxidants (vitamins A, E, and C) administration could accelerate 

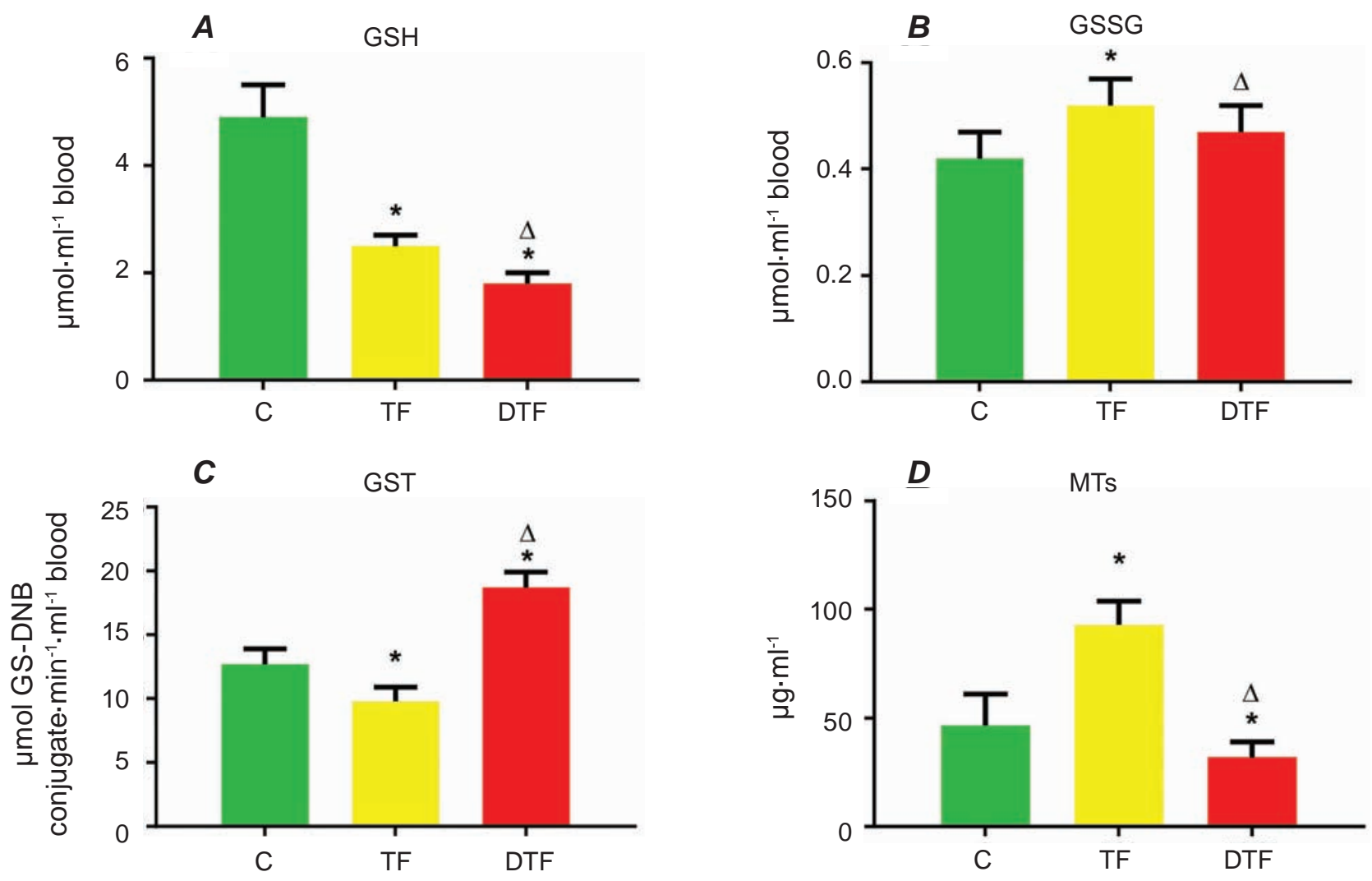

Fig. 2. The status of thiol pool in the blood of young men without (TF) and with (DTF) diabetes as concomitant pathology soon after a tibia fracture. A: GSH, B: GSSG, C: glutathione-S-transferase activity and D: metallothioneins. Data are present as means $\pm S D(n=12)$
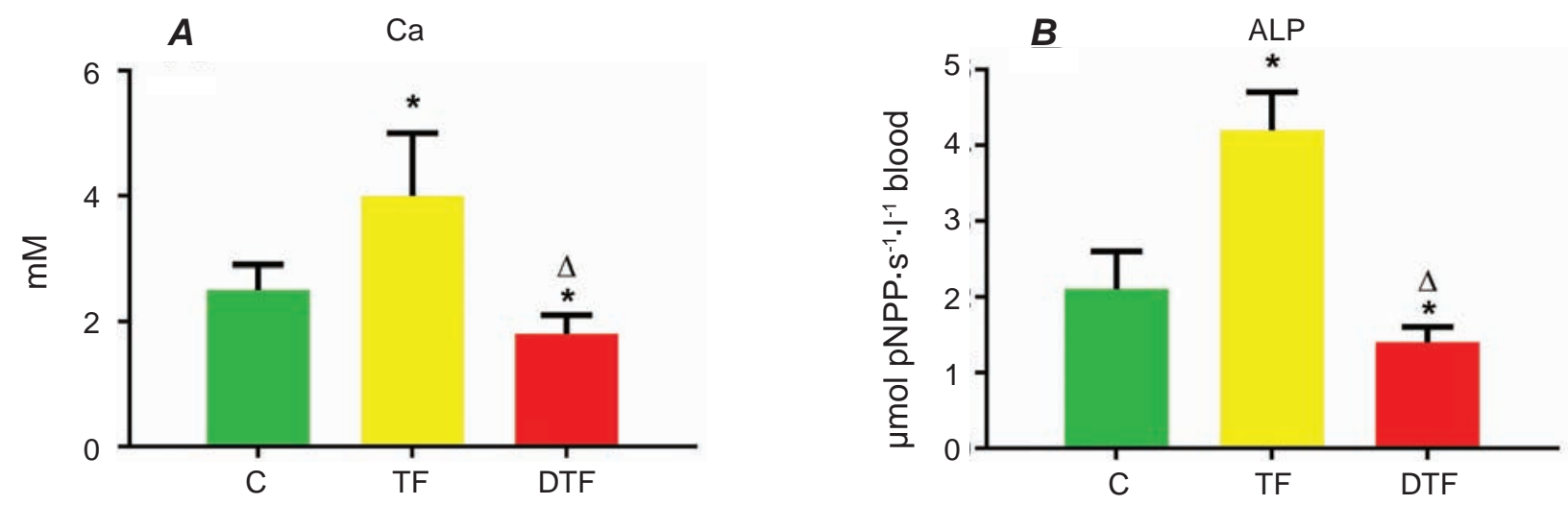

Fig. 3. Total calcium concentration (A) and alkaline phosphatase activity (B) in the blood of young men without (TF) and with (DTF) diabetes as concomitant pathology soon after a tibia fracture. Data for the indices are present as means $\pm S D(n=12)$

bone healing and has resulted in higher osteocalcin level and the activity of alkaline phosphatase in the plasma of patients [35], but further study is needed.

In last decades it has been proven that the enhanced oxidative stress could affect the osteoblast differentiation, proliferation or cell death $[36,37]$.
The one possible mechanism of ROS-mediated osteoclast/osteoblast metabolism and bone remodeling should relate to the stress-sensitive regulator of cellular homeostasis, namely Nuclear factor (erythroid-derived 2)-like 2 (Nrf2). Up-to-date the experimental evidence for the effect of Nrf2 on the bone 

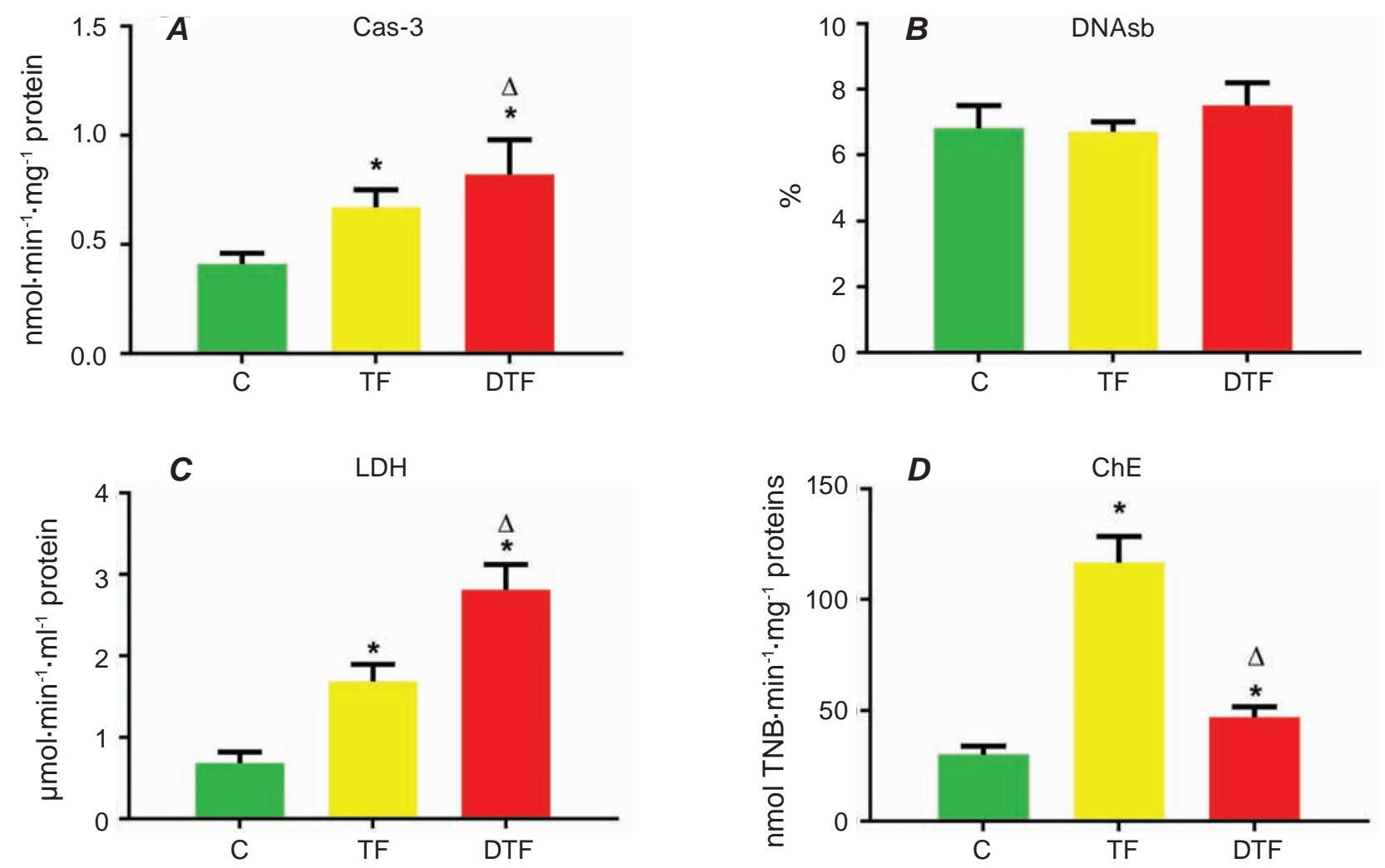

Fig. 4. Biomarkers of cytotoxicity in the blood of young men without (TF) and with (DTF) diabetes as concomitant pathology soon after a tibia fracture. Data for A: caspase 3 activity, B: DNA strand break, micronuclei, $C$ : lactate dehydrogenase activity, $\mathbf{D}$ : cholinesterase activity are present as means $\pm S D(n=12)$

remodeling and healing is limited [38, 39]. It was shown that Nrf2 deficiency leads to enhanced bone turnover and the predominance of bone resorption [39]. When tibia fracture befalls, ROS overflow occur. Moreover, as shown on the present experimental model, the ROS accumulation (in particular in DTF group) coupled with the impair of cellular thiols, namely MTs and glutathione, disturbed bone healing after fracture. Obviously, manipulations with Nrf2 should optimize efficiency of bone remodeling via regulation of antioxidants/prooxidants balance, alteration of oxidative stress genes and affection of mitochondrial ROS production [40], but further studies are needed.

Levels of free radicals have been reported to be increased in the osteoporosis, chronic inflammatory diseases and diabetes [41]. In the present study, both TBARS and protein carbonyls increased in all studied patients, but the integral oxidative stress index revealed subtle difference in DTF vs TF appeared as more serious oxidative damage in DTF persons. Meanwhile, bone fractures have stimulated the overproduction of free radicals by a number of phagocytes, diabetes itself caused a reduction in an- tioxidant levels, because of high level of advanced glycation end products that are able to increase ROS formation and impair antioxidant systems [42]. Obviously, all these initials should entail an increase in susceptibility to oxidative stress. Also, the long-term impact of oxidative stress on bones under diabetes could impair regulation and proliferation of osteocytes, osteoclasts and mesenchymal stem cells and as a result impair bone healing after fracture [36, 43].

It has proved by TUNEL labeling of murine models that apoptosis should play an important role at the beginning of bone remodeling during fracture healing, but its role has remained contradictory. On the one hand, caspase-3 deficient mice showed significant skeletal defects, which were related to reducin proliferation rates and impaired osteogenic differentiation of bone marrow stromal stem cells [44]. Furthermore, caspase-3 inhibitor evoked advanced bone loss in ovariectomized mice [44]. On the other hand, lower level of apoptosis-related factors Cyt C, Apaf- 1 and caspase-9 in bone tissue of patients after alendronate treatment was in a good correlation with higher bone density and faster bone metabolism [45]. Also, apoptosis of osteocytes in 
$\boldsymbol{A}$

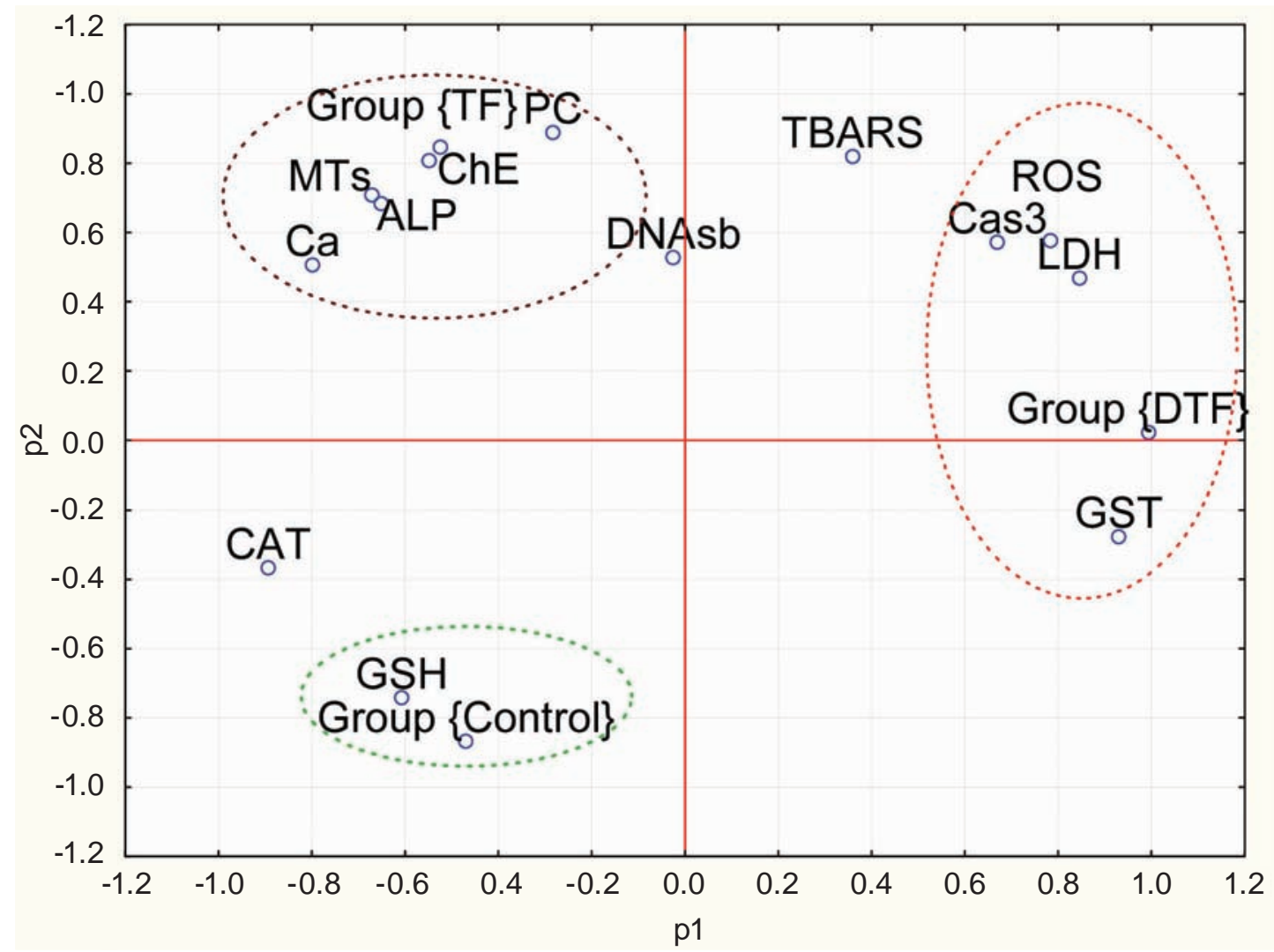

$B$

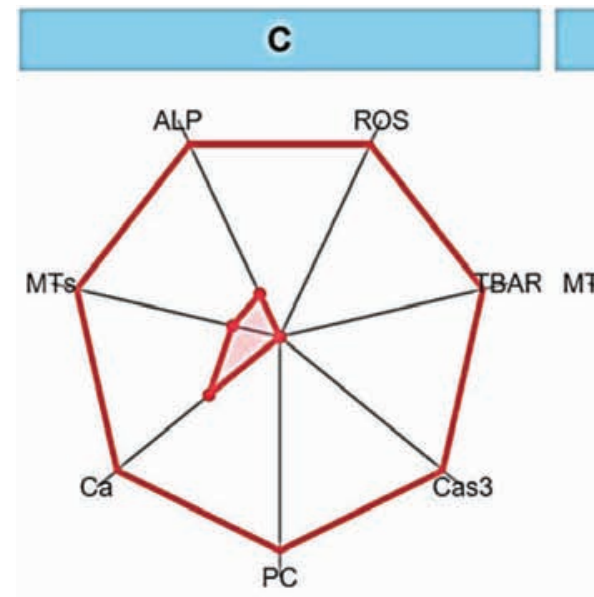

TF

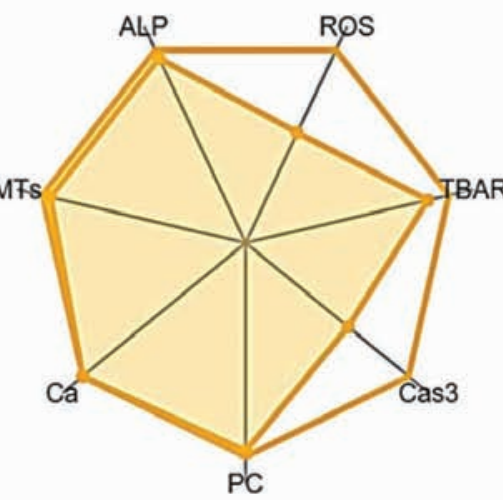

TFD

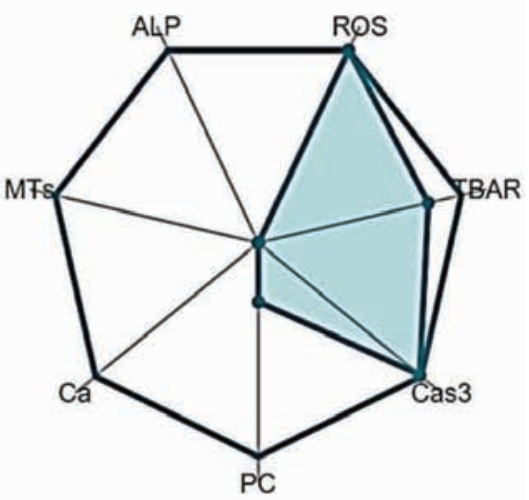

Fig. 5. A: Principal component analysis with NIPALS algorithm of all biological traits of young men without and with diabetes as concomitant pathology soon after a tibia fracture. $\mathbf{B}$ : The graphical representation of the integrated biomarker response index of young men without and with diabetes as concomitant pathology soon after a tibia fracture

mice caused an increas in osteocytic RANKL, precedes bone resorption and bone loss [46]. Highly likely, apoptosis in osteocytes increased (due to caspase 3 activation) when a tibia fracture accompanied by T2D and impair bone healing. It agrees with serious oxidative damage, low level of bone markers namely calcium and ALP which were signifi- cantly decreased: Cas-3 $=-0.014+0.0011 \times \mathrm{ROS}^{*}-$ $0.056 \times \mathrm{Ca}+0.00005 \times \mathrm{ALP}, \mathrm{F}_{3,20}=28.32, P<0.0001$.

It has been asserted that MTs play an antiapoptotic role in the post-traumatic process owing to strong antioxidant properties and anti-inflammatory potentials [15]. Our results revealed that MTs response to trauma depended on person's 
initial health status. T2D impaired MTs ability to protect organisms against overexpressed ROS and subsequently deeper oxidative stress (according to IOS) and higher intensity of apoptosis in DTF patients. Our results are consistent with reported data showing that MT-null mice were more susceptible to $\mathrm{CdCl}_{2}$-induced bone injury than wild-type mice. They were characterized by the more marked loss of bone mass related to dry bone weight, defatted bone weight, bone ash weight, and total calcium content [47].

In the present study, we observed a statistically significant increase in GST activity in DTF group as compared to controls and TF (Fig. 2). Increased level of GST seen in DTF persons with diabetes could be a manifestation of increased ROS generation as a result of prolonged hyperglycemia as well as a significant decreasing in GSH in mentioned group [48]. The correlation analysis revealed that GST and GSH are in a reverse correlation $(r=-0.67, P<0.01)$, which is in accord with previous studies $[48,49]$. Obviously, GST is highly likely to have a protective role in patients with diabetes after a tibia fracture but the increase in GST would not be sufficient enough to tackle ROS.

Cholinergic components and antagonist of acetylcholine receptors affect bone metabolism [50, 51]. In particular recent studies have proven that cholinesterase is essential for osteogenesis and chondrogenesis [52]. Also, acetylcholine induced cell proliferation and reduced alkaline phosphatase activity via nicotinic and muscarinic acetylcholine receptors in murine primary osteoblasts in vitro [50]. Our results clarified a close relation between cholinesterase and alkaline phosphatase soon after a tibia fracture $(r=0.92, P<0.001)$. Highly likely cholinesterase plays a possible role in bone healing via regulating the proliferation and differentiation of osteoblasts.

To sum up, the integrated analysis of stressresponsive systems and signs of molecular lesions underlined the common and particular features of bone healing in young men without and with diabetes. In general inhibition of enzymatic and nonenzymatic antioxidants, the redox-equilibrium shift to the prooxidant processes, activation of caspasemediated apoptosis and the disturbance of the balance of anaerobic/aerobic glycolysis occurred in patients soon after a tibia fracture. Diabetes mellitus (T2D) promotes specific features of healing related to glutathione-S-transferase activation and specific bone markers, namely total calcium level and alka- line phosphatase deterioration. Also, diabetes mellitus strongly affected the cellular thiol pool, including metallothioneins and reduced glutathione. Moreover, inhibition of cellular thiols was in a good agreement with breakdown of studied specific markers of bone healing $(r>0.82, P<0.001)$. Further studies are needed to clarify the potentials of antioxidant therapy after bone fracture, in particularly upon with diabetes in order to attenuate the negative effects caused by ROS.

Conflict of interest. The authors declare that they have no competing interest.

Ethical approval. All procedures that involve performed human participants were in accordance with the ethical standards of the institutional and/ or national research committee and with the 1964 Helsinki declaration and its later amendments or comparable ethical standards.

Acknowledgements. This work has been granted by the Ministry of Education and Science of Ukraine (P. \# 133B) and partially by Alexander von Humboldt Stiftung for HF.

\section{ОКИСНИЙ СТРЕС ТА ВИСНАЖЕННЯ ПУЛУ ТІОЛІВ ПОРУШУЄ ПРОЦЕС ЗАГОЕННЯ ПЕРЕЛОМУ ГОМІЛКОВОЇ КІСТКИ В МОЛОДИХ ЧОЛОВІКІВ ІЗ ДІАБЕТОМ 2-ГО ТИПУ}
Г. І. Фальфушинська ${ }^{1 凶}$, О. І. Горин
Д. В. Познанський, Д. В. Осадчук²,
Т. О. Савчин ${ }^{3}$, Т. I. Крииькийㄹ, Л. С. Мерва C. 3. Храбра ${ }^{1}$
${ }^{1}$ Тернопільський національний педагогічний університет імені Володимира Гнатюка, Україна;
${ }^{2}$ Тернопільський національний медичний університет імені І.Я. Горбачевського, Україна;
${ }^{3}$ Тернопільський національний технічний університет імені Івана Пулюя, Україна; 凶e-mail: falfushynska@tnpu.edu.ua

Цукровий діабет - метаболічне захворювання, яке супроводжується підвищеним ризиком переломів та порушує процес формування кісткової тканини. Метою нашої роботи було оцінити параметри окисного стресу, вміст металотіонеїнів (МТ), метаболічні зміни та ознаки цитотоксичності в крові молодих чоловіків 3 переломами великогомілкової кістки хворих на діабет 2-го типу (DTF-група) та які не мали 
відповідної патології (ТF-група) у функціональному взаємозв'язку з показниками формування кісткової тканини. Вміст активних форм оксигену (АФО) визначали за допомогою специфічного флуоресцентного барвника дигідрородаміну, фрагментацію ДНК оцінювали використовуючи флуоресцентний барвник Hoescht 33342, активність каспази-3 вимірювали за допомогою ацетил-Asp-Glu-Val-Asp n-нітроаналіду. Інші показники визначали стандартними спектрометричними методами. Згідно 3 одержаними результатами діабет 2-го типу істотно впливав на загоєння перелому. Зміни показників в обстежених групи DTF були істотнішими порівняно з групою TF. У пацієнтів TF- та, особливо, DTF-груп перелом кістки зумовлював значне пригнічення активності та/або зменшення рівня антиоксидантів узгоджено зі збільшенням ознак окисного ушкодження. Перелом гомілкової кістки також детермінував групово-специфічні зміни вмісту металотіонеїнів. Зокрема, у пацієнтів групи TF за перелому вміст МТ збільшувався, тоді як діабет спричиняв зменшення показника. Також у групі DTF істотно зменшувався і вміст іншого клітинного тіолу - глутатіону (на -64\%). Перелом великогомілкової кістки призводив до прояву ознак цитотоксичності, в тому числі збільшував активність лактатдегідрогенази (ЛДГ), холінестерази та каспази-3 - ключового ефектора апоптозу в остеокластах. Активність лужної фосфатази та вміст кальцію як показників ефективного процесу ремоделювання кісткової тканини зростали лише у TF-групі. До найвагоміших показників для диференціації груп належать концентрація АФО, активність каспази 3 , глутатіонтрансферази і ЛДГ, які, в основному, асоціюються з групою DTF. Відтак, діабет 2-го типу порушує процес загоєння кісткової тканини за умов тривалого окисного стресу та виснаження клітинного пулу тіолів, які зумовлюють ініціацію апоптозу та фрагментацію ДНК. Одержані результати відображають функціональний взаємозв'язок між посиленням окисного стресу та пригніченням маркерів ефективного ремоделювання кістки і є підгрунтям для подальших досліджень 3 вивчення ролі про- та антиоксидантів у загоєнні кісток.

К л юч о в і слов в: перелом гомілки, окисний стрес, діабет 2-го типу, показники формування кісток.

\section{References}

1. Amin S, Achenbach SJ, Atkinson EJ, Khosla S, Melton LJ 3rd. Trends in fracture incidence: a population-based study over 20 years. $J$ Bone Miner Res. 2014; 29(3): 581-589.

2. Alemdaroğlu KB, Tiftikçi U, Iltar S, Aydoğan NH, Kara T, Atlihan D, Ateşalp AS. Factors affecting the fracture healing in treatment of tibial shaft fractures with circular external fixator. Injury. 2009; 40(11): 1151-1156.

3. Mirhadi S, Ashwood N, Karagkevrekis B. Factors influencing fracture healing. Trauma. 2013; 15(2): 140-155.

4. Hernandez RK, Do TP, Critchlow CW, Dent RE, Jick SS. Patient-related risk factors for fracturehealing complications in the United Kingdom General Practice Research Database. Acta Orthop. 2012; 83(6): 653-660.

5. Singh R, Devi S, Gollen R. Role of free radical in atherosclerosis, diabetes and dyslipidaemia: larger-than-life. Diabetes Metab Res Rev. 2015; 31(2): 113-126.

6. Valko M, Rhodes CJ, Moncol J, Izakovic M, Mazur M. Free radicals, metals and antioxidants in oxidative stress-induced cancer. Chem Biol Interact. 2006; 160(1): 1-40.

7. Hensley K, Robinson KA, Gabbita SP, Salsman S, Floyd RA. Reactive oxygen species, cell signaling, and cell injury. Free Radic Biol Med. 2000; 28(10): 1456-1462.

8. Domazetovic V, Marcucci G, Iantomasi T, Brandi ML, Vincenzini MT. Oxidative stress in bone remodeling: role of antioxidants. Clin Cases Miner Bone Metab. 2017; 14(2): 209-216.

9. Marin C, Luyten FP, Van der Schueren B, Kerckhofs G, Vandamme K. The Impact of Type 2 Diabetes on Bone Fracture Healing. Front Endocrinol (Lausanne). 2018; 9: 6.

10. Sundararaghavan V, Mazur MM, Evans B, Liu J, Ebraheim NA. Diabetes and bone health: latest evidence and clinical implications. Ther $A d v$ Musculoskelet Dis. 2017; 9(3): 67-74.

11. Sanguineti R, Puddu A, Mach F, Montecucco F, Viviani GL. Advanced glycation end products play adverse proinflammatory activities in osteoporosis. Mediators Inflamm. 2014; 2014: 975872.

12. Jiao H, Xiao E, Graves DT. Diabetes and Its Effect on Bone and Fracture Healing. Curr Osteoporos Rep. 2015; 13(5): 327-335. 
13. Gagnon C, Magliano DJ, Ebeling PR, Dunstan DW, Zimmet PZ, Shaw JE, Daly RM. Association between hyperglycaemia and fracture risk in non-diabetic middle-aged and older Australians: a national, population-based prospective study (AusDiab). Osteoporos Int. 2010; 21(12): 2067-2074.

14. Maret W. Redox biochemistry of mammalian metallothioneins. J Biol Inorg Chem. 2011; 16(7): 1079-1086.

15. Won $\mathrm{Y}$, Shin $\mathrm{Y}$, Chun $\mathrm{CH}$, Cho $\mathrm{Y}$, Ha CW, Kim JH, Chun JS. Pleiotropic roles of metallothioneins as regulators of chondrocyte apoptosis and catabolic and anabolic pathways during osteoarthritis pathogenesis. Ann Rheum Dis. 2016; 75(11): 2045-2052.

16. Lowell BB, Shulman GI. Mitochondrial dysfunction and type 2 diabetes. Science. 2005; 307(5708): 384-387.

17. Falfushynska HI, Gnatyshyna LL, Deneha HV, Osadchuk OY, Stoliar OB. Manifestations of oxidative stress and molecular damages in ovarian cancer tissue. Ukr Biochem J. 2015; 87(5): 93-102.

18. Falfushynska HI, Horyn OI, Khoma VV, Tereshchuk GV, Osadchuk DV, Rusnak NI, Stoliar OB. Evaluation of metallothioneins, oxidative stress and signs of cytotoxicity in young obese women. Ukr Biochem J. 2018; 90(5): 71-80.

19. Falfushynska HI, Gnatyshyna LL, Osadchuk OY, Shidlovski VO, Stoliar OB. Trace elements storage peculiarities and metallothionein content in human thyroid gland under iodine deficiency euthyroid nodular goiter. Ukr Biochem J. 2014; 86(3): 107-113. (In Ukrainian).

20. Falfushynska HI, Gnatyshyna LL, Osadchuk DV, Shidlovski VO, Stoliar OB. Metal-binding functions and antioxidant properties in human thyroid gland under iodine deficient nodular colloidal goiter. Ukr Biokhim Zhurn. 2011; 83(6): 92-97. (In Ukrainian).

21. Aebi H, Wyss SR, Scherz B, Skvaril F. Heterogeneity of erythrocyte catalase II. Isolation and characterization of normal and variant erythrocyte catalase and their subunits. Eur J Biochem. 1974; 48(1): 137-145.

22. Viarengo A, Burlando B, Cavaletto M, Marchi B, Ponzano E, Blasco J. Role of metallothionein against oxidative stress in the mussel Mytilus galloprovincialis. Am J Physiol. 1999; 277(6): R1612-R1619.
23. Reznick AZ, Packer L. Oxidative damage to proteins: spectrophotometric method forcarbonyl assay. Methods Enzymol. 1994;233:357-63.

24. Ohkawa H, Ohishi N, Yagi K. Assay for lipid peroxides in animal tissues by thiobarbituric acid reaction. Anal Biochem. 1979; 95(2): 351358.

25. Anderson ME. Determination of glutathione and glutathione disulfide in biological samples. Methods Enzymol. 1985; 113: 548-555.

26. Griffith OW. Determination of glutathione and glutathione disulfide using glutathione reductase and 2-vinylpyridine. Anal Biochem. 1980; 106(1): 207-212.

27. Viarengo A, Ponzano E, Dondero F, Fabbri R. A simple spectrophotometric method for metallothionein evaluation in marine organisms: an application to Mediterranean and Antarctic molluscs. Mar Environ Res. 1997; 44(1): 69-84.

28. Habig WH, Pabst MJ, Jakoby WB. Glutathione S-transferases. The first enzymatic step in mercapturic acid formation. J Biol Chem. 1974; 249(22): 7130-7139.

29. Bergmeyer HU, Bernt E. UV-Assay with Pyruvate and NADH. Methods Enzym Anal. 1974: 574-579.

30. Ellman GL, Courtney KD, Andres V, Featherstone RM. A new and rapid colorimetric determination of acetylcholinesterase activity. Biochem Pharmacol. 1961; 7: 88-95.

31. Bonomini M, Dottori S, Amoroso L, Arduini A, Sirolli V. Increased platelet phosphatidylserine exposure and caspase activation in chronic uremia. J Thromb Haemost. 2004; 2(8): 12751281.

32. Olive PL. DNA precipitation assay: a rapid and simple method for detecting DNA damage in mammalian cells. Environ Mol Mutagen. 1988; 11(4): 487-495.

33. Camozzi V, Tossi A, Simoni E, Pagani F, Francucci CM, Moro L. Role of biochemical markers of bone remodeling in clinical practice. J Endocrinol Invest. 2007; 30(6 Suppl): 13-17.

34. Kruse K, Kracht U. Evaluation of serum osteocalcin as an index of altered bone metabolism. Eur J Pediatr. 1986; 145(1-2): 27-33.

35. Sandukji A, Al-Sawaf H, Mohamadin A, Alrashidi Y, Sheweita SA. Oxidative stress and bone markers in plasma of patients with longbone fixative surgery: role of antioxidants. Hum Exp Toxicol. 2011; 30(6): 435-442. 
36. Almeida M, O'Brien CA. Basic biology of skeletal aging: role of stress response pathways. J Gerontol A Biol Sci Med Sci. 2013; 68(10): 1197-1208.

37. Li M, Zhao L, Liu J, Liu AL, Zeng WS, Luo SQ, Bai XC. Hydrogen peroxide induces G2 cell cycle arrest and inhibits cell proliferation in osteoblasts. Anat Rec (Hoboken). 2009; 292(8): 1107-1113.

38. Sun YX, Xu AH, Yang Y, Li J. Role of Nrf2 in bone metabolism. J Biomed Sci. 2015; 22: 101.

39. Ibáñez L, Ferrándiz ML, Brines R, Guede D, Cuadrado A, Alcaraz MJ. Effects of Nrf2 deficiency on bone microarchitecture in an experimental model of osteoporosis. Oxid Med Cell Longev. 2014; 2014: 726590.

40. Lazaro I, Lopez-Sanz L, Bernal S, Oguiza A, Recio C, Melgar 1, Jimenez-Castilla L, Egido J, Madrigal-Matute J, Gomez-Guerrero C. Nrf2 Activation Provides Atheroprotection in Diabetic Mice Through Concerted Upregulation of Antioxidant, Anti-inflammatory, and Autophagy Mechanisms. Front Pharmacol. 2018; 9: 819.

41. Rao LG, Rao AV. Oxidative Stress and Antioxidants in the Risk of Osteoporosis - Role of the Antioxidants Lycopene and Polyphenols. in: Topics in Osteoporosis. 2013.

42. Niedowicz DM, Daleke DL. The role of oxidative stress in diabetic complications. Cell Biochem Biophys. 2005; 43(2): 289-330.

43. Morikawa D, Nojiri H, Saita Y, Kobayashi K, Watanabe K, Ozawa Y, Koike M, Asou Y, Takaku T, Kaneko K, Shimizu T. Cytoplasmic reactive oxygen species and SOD1 regulate bone mass during mechanical unloading. J Bone Miner Res. 2013; 28(11): 2368-2380.

44. Miura M, Chen XD, Allen MR, Bi Y, Gronthos S, Seo BM, Lakhani S, Flavell RA, Feng XH, Robey PG, Young M, Shi S. A crucial role of caspase-3 in osteogenic differentiation of bone marrow stromal stem cells. J Clin Invest. 2004; 114(12): 1704-1713.
45. Li H, Li C, Yi X, Liu H, Wang Y. Effects of sodium alendronate on osteoporosis and apoptosis-related factors Cyt C, Apaf-1 and caspase-9. Biomed Res. 2018; 29(3): 416-420.

46. Plotkin LI, Gortazar AR, Davis HM, Condon KW, Gabilondo $\mathrm{H}$, Maycas $\mathrm{M}$, Allen MR, Bellido T. Inhibition of osteocyte apoptosis prevents the increase in osteocytic receptor activator of nuclear factor $\kappa \mathrm{B}$ ligand (RANKL) but does not stop bone resorption or the loss of bone induced by unloading. $J$ Biol Chem. 2015; 290(31): 18934-18942.

47. Habeebu SS, Liu J, Liu Y, Klaassen CD. Metallothionein-null mice are more susceptible than wild-type mice to chronic $\mathrm{CdCl}(2)$-induced bone injury. Toxicol Sci. 2000; 56(1): 211-219.

48. Sharma P, Senthilkumar RD, Brahmachari V, Sundaramoorthy E, Mahajan A, Sharma A, Sengupta S. Mining literature for a comprehensive pathway analysis: a case study for retrieval of homocysteine related genes for genetic and epigenetic studies. Lipids Health Dis. 2006; 5: 1.

49. Maurya PK, Rizvi SI. Age-dependent changes in glutathione-s-transferase: correlation with total plasma antioxidant potential and red cell intracellular glutathione. Indian J Clin Biochem. 2010; 25(4): 398-400.

50. Sato T, Abe T, Chida D, Nakamoto N, Hori N, Kokabu S, Sakata Y, Tomaru Y, Iwata T, Usui M, Aiko K, Yoda T. Functional role of acetylcholine and the expression of cholinergic receptors and components in osteoblasts. FEBS Lett. 2010; 584(4): 817-824.

51. Liu PS, Chen YY, Feng CK, Lin YH, Yu TC. Muscarinic acetylcholine receptors present in human osteoblast and bone tissue. Eur $J$ Pharmacol. 2011; 650(1): 34-40.

52. Inkson CA, Brabbs AC, Grewal TS, Skerry TM, Genever PG. Characterization of acetylcholinesterase expression and secretion during osteoblast differentiation. Bone. 2004; 35(4): 819-827. 